\title{
Biosensitivity of Molybdenum Disulfide for Monitoring Breast Cancer Marker CA15-3 Using Quartz Crystal Microbalance
}

\author{
Suhua Lin, Jing Wang, Yilin Lin, Xiaohua Wang ${ }^{*}$ \\ East China Normal University, 500 dongchuan road, minhang district, Shanghai \\ 201100 \\ *E-mail: xhwang@ee.ecnu.edu.cn
}

doi: $10.20964 / 2021.01 .02$

Received: 2 July 2020 / Accepted: 17 October 2020 / Published: 30 November 2020

\begin{abstract}
This paper verified the biosensors of molybdenum disulfide $\left(\mathrm{MoS}_{2}\right)$ and the colloidal gold probe to amplify signals studied by using quartz crystal microbalance (QCM) sensor. The chemical reaction was resulted in the formation of colloidal gold probes by immune colloidal gold technique and then verified by double antibody sandwich techniques (ELISA). Nanometer $\mathrm{MoS}_{2}$ as the sensitive material of sensor was produced by hydrothermal method. The scanning electron microscope (SEM) and transmission electron microscope (TEM) electron microscopy showed that the gold nanoparticles were successfully modified on anti-CA15-3 antibodies and the prepared $M o S_{2}$ was typical two-dimensional material with a hexagonal sheet structure. We found that these QCM sensors had high sensitivity (26.303 \pm $1.139 \mathrm{~Hz} /$ scale, $1 \mathrm{U} / \mathrm{ml})$ and good linearity $(0.960 \pm 0.013)$ within the concentration range of CA153 between $0.5 \mathrm{U} / \mathrm{ml}$ and $100 \mathrm{U} / \mathrm{ml}$. The results show that the response time of the system was less than $20 \mathrm{~s}$, had reproducibility and selectivity. It indicated that nanometer $\mathrm{MoS}_{2}$ is a good biosensor material.
\end{abstract}

Keyword: molybdenum disulfide; bio-sensitivity; quartz crystal microbalance sensor; immune colloidal gold technique; double antibody sandwich techniques; CA15-3 concentration detection

\section{$\underline{\text { FULL TEXT }}$}

(C) 2021 The Authors. Published by ESG (www.electrochemsci.org). This article is an open access article distributed under the terms and conditions of the Creative Commons Attribution license (http://creativecommons.org/licenses/by/4.0/). 